\title{
Post-crash neoliberalism in theory and practice
}

\begin{abstract}
Despite the massive state interventions into financial markets following the crash of 2007, the academic literature on the political-economic theory and practice of neoliberalism - a phenomenon often (mis)identified as equivalent to 'free market' fundamentalism or a second wave of laissez-faire - has continued to flourish, rather than decline in the post-crash era. This article discusses three recent books that offer insights into the resilience of neoliberalism in theory and practice. While all three books were published shortly before the onset of the new political crisis in the West, represented by Brexit, Trump and the rise of the far right, it is argued here that their analyses of post-crash neoliberalism in theory and practice offer useful clues as to what may lie ahead.

Ban, C. (2016), Ruling Ideas: How Global Neoliberalism Goes Local, Oxford University Press: New York, £20.99, 301pp, ISBN 9780190600396.

Davison, S. and Harris, K. (eds.) (2015), The Neoliberal Crisis, Lawrence and Wishart Ltd: London $€ 11.99,112 p p$, ISBN 9781910448076.

Hoskins, A. and Tulloch, J. (2016), Risk and Hyperconnectivity: Media and Memories of Neoliberalism, Oxford University Press: New York, £19.99, 333pp, ISBN 9780199375509.
\end{abstract}

Keywords: Neoliberalism, financial crisis, post-crash economics, nationalism, right wing populism.

\section{Introduction}

A decade on from the onset of the global financial crisis, its effects are still being felt acutely by millions of people around the world. Cuts to public services and welfare, stagnating wages and consequent cost of living and housing crises, have pervaded 'core' Western states. These post-crash effects are of course even more keenly felt in those societies that entered the crisis period with less. People living at the 'periphery' of the EU, in Greece and Spain for example, have suffered from widespread unemployment, and the total collapse of some public services, while economies of the global South have borne the brunt of sudden changes to global chains of production and consumption.

An early response from the governments of some core states was to intervene into financial markets through bailouts, using public money and labels like 'fiscal stimuli' to shore-up those private sector actors deemed 'too big to fail'. One side-effect of these state interventions was to call into question the dominance of 'neoliberalism'. This term, which first emerged in the mid-20 $0^{\text {th }}$ century, but really exploded in academic usage from the 1990s onward (Boas and Gans-Morse, 2009), has often been equated with a second wave of the laissez-faire economic policy that was lauded by some Western political economists in the $19^{\text {th }}$ century; the Wikipedia page on neoliberalism, for instance (the influence of which may be loosely inferred from the 1.7 million views it received in 2016 - an average of 4,570 views per day) defines it in precisely this way (Wikipedia, 2017). A commonplace understanding of neoliberalism is that it is a theory, emerging especially from the work of Austrian and Chicago School political economists like Friedrich Hayek and later Milton Friedman, and practice realised in the West from the 1980s onward, that privileges 'free' market mechanisms over state regulation, and 
privatisation and competition over public ownership and social security (Steger, 2005; Steger and Roy, 2010).

On this view of neoliberalism, it might be expected that the interventionist response of core, supposedly 'neoliberal' states like the US and UK to the crash indicated the beginning of the end of neoliberalism as a "globally dominant" ideology

(Schwartzmantel, 2008). However, much scholarship on neoliberalism - often drawing upon the Marxian, Gramscian and Foucauldian traditions of critical political economy has suggested that it has never been purely a project of free market fundamentalism or a renewal of laissez-faire. Instead, it has been argued, a clearly defined role for the state as a referee between citizen-consumers and businesses, and as the creator and guarantor of competitive market conditions in new social spheres is essential to the neoliberal creed even as it is laid out in the work of Hayek and Friedman. State interventions are not, therefore, unthinkable in neoliberal societies, at least where such interventions are likely to protect or extend capitalist markets and their constituent businesses.

Neoliberalism remains a growth industry in critical scholarship, with dozens of new books and journal articles being published each year, even as we approach the 10-year anniversary of the crash. In this article, I critically evaluate three such recent contributions, published by the editors of the Soundings journal, by Cornel Ban, and by Andrew Hoskins and John Tulloch. These texts straddle the disciplinary boundaries of politics, international relations, media and cultural studies, but have in common that each critically explores different aspects of post-crash neoliberalism in theory and practice.

The Neoliberal Crisis (2015) is a short collection of essays from the founding editors of Soundings, centring on the late Stuart Hall's 'The neoliberal revolution', originally published in Soundings in 2011. The book seeks to clarify high level discussions of neoliberalism and crisis from the perspective of Gramscian 'conjunctural analysis' and is pitched as a companion piece to After Neoliberalism? The Kilburn Manifesto (also 2015), the Soundings editors' call to arms, which sought to:

$[\mathrm{H}]$ elp people on the left think more about how we can shift the parameters of the [post-crash] debate, from one concerning small palliative and restorative measures, to one which opens the way for moving towards a new political era and new understandings of what constitutes the good society (Hall et al. (eds.), 2015: 9).

Cornel Ban's Ruling Ideas: How Global Neoliberalism Goes Local(2016), meanwhile, takes a highly structured comparative international political economy approach, seeking to understand the varying experiences of 'global neoliberalism' at the local level. Drawing upon Karl Polanyi's concepts of embeddedness and disembeddedness, Ban compares and contrasts the Spanish and Romanian experiences of neoliberal transformation. In doing so, his book highlights some of the crucial differences in the way neoliberalism translates from theories to practices and from the global abstract to the local concrete context.

Finally, Hoskins and Tulloch's Risk and Hyperconnectivity: Media and Memories of Neoliberalism (2016) approaches the analysis of post-crash neoliberalism in theory and 
practice from an interdiscplinary perspective, representing the two authors' diverse backgrounds, but focused on media representations of risk in the present neoliberal era.

In this article I approach the three texts thematically, in three parts. Firstly, I critically examine the theorisations of post-crash neoliberalism they imply, propose or extend. Next, I explore their varied reflections on post-crash neoliberalism in practice, or 'actually existing neoliberalism'. And finally, I draw out and examine how the three texts might speak to the current crisis of the Western political mainstream - Brexit, the rise of Trump and the far right - and what clues they might give us to what is to come next.

\section{Post-crash neoliberalism in theory}

As Ruling Ideas notes, far from sparking a decline in discussions of neoliberalism, the post-crash era has in fact stimulated a 'new wave of literature' (p. 8). Much of this recent literature has taken as its conceptual point of departure the fact that commonplace definitions of neoliberalism as equivalent to 'market fundamentalism' or - as the Wikipedia entry has it at time of writing - "the 20th century resurgence of 19th century ideas associated with laissez-faire economic liberalism" (Wikipedia, 2017) - are fundamentally mistaken (e.g. Amable, 2010). The presumption of a strong anti-statist tendency, of a drive toward pure market governance, fails to account for the specific role of the state outlined in the work of neoliberal scholars like Hayek and Friedman. Neoliberalism in both theory and practice has required the state as the engine for extending and monitoring markets and as an "umpire to interpret and enforce the rules" around the interactions between citizens-as-consumers and the markets (Friedman, 2002 , p. 15). To talk of the continued influence of neoliberalism in a post-crash, postbailout era necessitates a clear articulation of what is meant by neoliberalism if not the resurgence of laissez-faire. The three books discussed here each provides a unique theorisation.

In The Neo-Liberal Crisis the definition of neoliberalism underpinning the book is established in Chapter 1, Hall's essay on the 'neoliberal revolution'. Here Hall notes that "the term 'neoliberal' is not a satisfactory one" since its "reference to the shaping influence of capitalism on modern life sounds recidivist to contemporary ears" (p. 13), but argues nevertheless for a "provisional conceptual identity" for neoliberalism focused on the notion of "the 'free, possessive individual', with the state cast as tyrannical and oppressive" (p. 14). In particular, Hall argues, this neoliberal imaginary is tied to a visceral opposition to the post-war welfare state or 'settlement', and to the "do-gooding, utopian sentimentality" which neoliberals believe has "enervated the nation's moral fibre, and eroded personal responsibility" (p. 15).

This conceptualisation of neoliberalism is certainly borne out by even a cursory reading of neoliberal 'classics' like Hayek's Road to Serfdom, where the author issues dire warnings against the "insidious effect" of social security (Hayek, 1944, p. 91). Meanwhile Hall offers a biting riposte to those who have suggested that neoliberalism is too conceptually slippery to be of use at all (e.g. Barnett, 2005), blaming a selfproclaimed and very "English" pragmatism which "often cannot see the practical efficacy of long-term, theoretical ideas" (p. 14). 
Neoliberalism, says Hall, "has many variants" and is "not one thing" (p. 16). It "evolves", beginning from some classical liberal ideas but rearticulating them with "a further 'market' inflexion" (p. 20). Ban's theorisation of neoliberalism in Ruling Ideas similarly notes that it is not "a seamless and steely behemoth, but an evolving hybrid whose every concrete manifestation is imbued with local flavours" (p. 3). In particular, Ban is keen to apply Karl Polanyi's concepts of embeddedness and disembeddedness to neoliberalism (pp. 12-13). The former denotes global market ideas as they are integrated with, and thus partially counter-balanced by, existing local ideas about economic policy, the latter a more 'pure' or radical imposition of global neoliberalism in a local context.

However, the theorisation Ban goes on to develop in Ruling Ideas is rather narrower than Hall's. In pursuit of a "revisionist definition" that is neither "very broad" nor "very narrow" (p. 8), Ban explicitly eschews both the increasingly popular Foucauldian approaches to conceptualising neoliberalism as "applicable [...] to the totality of human existence" (p. 7) and what he calls "excessively narrow definitions that construe neoliberalism as a contemporary version of laissez-faire" (p. 9). However, the "definitional strategy" he ultimately opts for seems curiously narrow by comparison to either of these approaches, since, for example, he asserts that to "understand what neoliberalism is, one has to understand what these arcane terms [Ricardian equivalence and the Laffer curve] mean" (p. 11).

Ban's definition thus situates neoliberalism as a largely or purely 'economic' theory and practice, requiring the specialist terminology of economists to engage with it. This is problematic inasmuch as one of the key achievements of neoliberalism itself, especially from the 'Third Way' era onward has arguable been the separation of politics and economy in intellectual labour and material practice - something Milton Friedman argued passionately for in his neoliberal opus Capitalism and Freedom (2002). The notion that to 'understand' economy necessitates serious engagement with this specialist pseudo-scientific idiom was absolutely central to propagating the neoliberal view that elected governments should have no more than a managerial or custodianship role in relation to economy and, by extension, that there 'is no alternative' to further marketization and privatisation.

It is therefore worth noting at this juncture that while both The Neo-Liberal Crisis and Risk and Hyperconnectivity offer broader and more "provisional" conceptualisations of neoliberalism, to use Hall's term, Ruling Ideas insists on a more specific approach. This approach comes at the risk of contributing to the reification of a key neoliberal division of intellectual labour. Ban writes of it:

In short, the book uses a middle-range definition of neoliberalism that overcomes the too broad / too narrow problem of existing approaches by focusing on economic theories and schools of thought as the core of the ideational side of neoliberalism (p. 17)

Here I must disagree with Ban's characterisation of his own definition. This definition is very narrow indeed. In particular, it loses sight of the deeply moral content of neoliberalism, which is in fact foregrounded in the classic works of neoliberal political- 
economy. "Economic theories and schools of thought" have never been confined to 'technical' issues like monetary policy, privatisation, macroeconomic 'levers' and so on. They are saturated, just as much as political theories and schools of thought, in ideas about how we ought to live together as societies, ideas about the 'good life', and neoliberalism is no exception. Ban's situating of neoliberalism as only existing on the 'economic' plane implies that the critique of neoliberalism is simply about competing economic rationalities, when in fact there is much more at stake, as the other books discussed in this article ably demonstrate.

Hoskins and Tulloch's theorisation of neoliberalism is rather less clear. The authors avoid an explicit definition but instead, in Chapter Two, "explore some key concepts" in "neoliberalization theory" (p. 23). What can be gathered from this exploration is that they firstly sympathise with the theories and histories of neoliberalism of Kim England and Kevin Ward (2007) and Daniel Stedman Jones (2012). In particular, they suggest that "our own project will be similar" to those which favour the term 'neoliberalization' over 'neoliberalism', because the former better represents the continuously unfolding nature of the phenomena it describes, whereas the latter implies an "end-state" (p. 32). In this respect, Risk and Hyperconnectivity, like The Neoliberal Crisis and Ruling Ideas shares a concern with the contingent, emergent and variegated nature of neoliberalism in practice.

In a subsequent passage that leans heavily - or, less charitably, too heavily - on two articles by Mitchell Dean, Hoskins and Tulloch also endorse a specific Foucauldian reading of post-crash neoliberalism as a mode of governmentality that places logics of exceptionalism, emergency, precaution and risk management at the centre of its governmental rationality (pp. 33-40). Dean's conceptualisation of neoliberalism, they argue, "adds to our position on connectivity thinking about powerful "gravitational memories"'” (p. 40). Hoskins and Tulloch are interested in "neoliberal modernity" to the extent that it is characterised by "hyperconnectivity", a "multidimensional mechanism of late modernity" affording "temporal proximity (and distance) to the past and to an emergent future [...] forging and reforging new assemblages of remembering and forgetting" (p. 11). This hyperconnectivity is lived out in the new "media ecologies" (p. 9) of the internet age, which in turn produces "new conflagration of risk actors, discourses and events" (ibid.). Risk and Hyperconnectivity is thus rather more dependent on 'high' social theory than either The Neoliberal Crisis or Ruling Ideas and as a result tends to employ a less accessible and more specialist vocabulary, at times with limited care for explanation. This author's translation of Hoskins and Tulloch's model is that they consider neoliberalism - a globalising, marketising set of ideas and practices of governance - to be reliant upon the newly and highly connected global media environment enabled by, for example, smart phones, social media platforms of Web 2.0, and other internet technologies. In particular, they see the social reproduction of neoliberalism as a governmental rationality or 'governmentality', in Foucault's terms, as dependent upon a media ecology that dominated by representations of risk, generating a catastrophic social imaginary that is wracked by fear about the future and in which memory is a vital and contested political terrain. 
In these three books, then, we find distinct and divergent theorisations of post-crash neoliberalism. It is tempting to synthesise them thus: in the post-crash era 'neoliberalism' signifies the continuously unfolding, and regionally and nationally divergent, process by which the post-war 'settlement' between capital and labour especially the welfare state and the principles of social security - is being overturned in favour of a more completely privatised, individualised and competitive capitalist social model. This ongoing transformation currently takes the form of a mixture of theoretical adaptations in economic policy to the 2007-present crisis, a revival of nationalism, and the new sense of risk and threat that is enabled by recent technological revolutions.

\section{Post-crash neoliberalism in practice}

In the same way that the 'really existing' or 'actually existing' socialism of the Stalinist, Maoist and other communist regimes established in the twentieth century diverged violently from the vision of socialism implied and described in the works of Marx and Engels (Nove, 2013), so none of the actual instantiations of neoliberalism in the world adhere completely to the theories of Hayek or Friedman. This has led to the coining of "actually existing neoliberalism" (Brenner and Theodore, 2002; Chandler, 2014).

In addition to the theorisations of post-crash neoliberalism in the three books under review, each also offers analysis of actually existing post-crash neoliberalism. The Neoliberal Crisis makes two fundamental contributions in this regard. Firstly, it decisively embeds the political history of the New Labour and Conservative-Liberal Democrat coalition governments within the trajectory of neoliberalism, thus going beyond the standard recognition that the Thatcher government inaugurated neoliberalism in British economic and social policy-making. Blairism, too, it is argued provided a new "hybrid" or "variant" of neoliberalism based on the so-called "Third Way', which aimed at and achieved "very important social reforms" including the minimum wage, but also bought fully into "the new managerial doctrine of public choice theory" and pressed ahead with privatisations and marketisations of public services and public property (pp. 22-23). Gordon Brown, as Britain's first post-crash Prime Minister, as Hall notes "did not fundamentally alter New Labour's neoliberal inclinations" and "admired the dynamism of American free-enterprise capitalism" (p. 26). The Conservative-Liberal Democrat coalition that followed initiated a vast programme of 'austerity' cuts that is still underway today, and which is based entirely upon neoliberal economic theory (as Ban's Ruling Ideas demonstrates at length). Like Thatcher's government, Hall argues that the Coalition "may be Conservatives but this is not a 'conserving' regime" (p. 28). The privatisation of parts of the NHS, the use of the 'localism' discourse as a means of effectively de-funding national public services, and a "phoney populism" based on concepts of 'community' and of course the 'Big Society' were key Coalition strategies for adapting post-crash neoliberalism (p. 29).

Secondly, The Neoliberal Crisis raises the question of how neoliberalism, before and during the crisis, is enmeshed with older trends in nationalism. This theme will, however, be picked up in the next section of the article.

The majority of Ruling Ideas (six of its nine chapters) is given over to developing a detailed and compelling narrative of comparative analysis, explaining how "real-existing 
neoliberalism" (p. 13) became established in Spain and Romania in the pre-crash era. At the heart of Ban's mixed methods research approach lies a systematic and persuasive re-construction (through analysis of policy texts, elite interviews, social network maps and other sources) of how neoliberal ideas were adopted and altered in his two case study countries.

Ban first shows how neoliberal ideas took hold in post-Franco Spain through a process of "editing" (p. 21), such that it was an "embedded" form of neoliberalism that was ultimately realised. He documents in meticulous detail the ideational process by which key policy influencers, especially Luis Angel Rojo, head of the Bank of Spain's Research Service and Professor of Macroeconomics at Complutense University of Madrid, introduced and "translated" global neoliberal economic ideas into Spanish policymaking circles (p. 43). The result was a form of embedded neoliberalism, developed by successive governments of both the Socialist and Popular (conservative) parties, which has been edited together with, for example:

ideas about the welfare state [...] that a higher minimum wage and minimum pension, more spending on affordable housing, and the establishment of a new social program for dependent persons would distribute the windfall revenues from the boom more evenly, while also representing a social investment in the country's labor force (p. 62).

Embedded Spanish neoliberalism has "deep roots", Ban argues, since the key macroeconomic figures who translated it were engaged in global policy elites, where neoliberal ideas predominated, even during Franco's rule (p. 114). In post-communist Romania, on the other hand, Ban tracks the emergence of a form of "disembedded" neoliberalism. Since the "poor state of international exchanges of economic ideas under Ceausescu" insulated Romanian economist from neoliberal influence throughout the Cold War period (p. 117), global neoliberalism actually found "few sympathetic interlocutors" in post-communist Romania (p. 96). So neoliberal ideas did not fully take hold until the late 1990s, following sustained external pressure. Ultimately the version of neoliberalism that was introduced to Romania was more radical than in Spain, since it did not need to be edited together with longstanding redistributive social and economic policies. But, like in Spain, the domestic actors who helped to achieve the eventual dominance of neoliberal economic ideas were also "clustered around the revolving door between academia and the central bank" (p. 80).

The final two chapters of Ban's book deal with neoliberalism in the post-crash era, or "neoliberalism's resilience since the Great Recession" (p. 181). In post-crash Spain there was, under Zapatero's Socialist government, initially a limited renewal of Keynesian macroeconomic policy - achievable, in Ban's view, because of the embedded nature of Spanish neoliberalism. An enormous stimulus package in 2008 that "balanced progressive redistribution with supply-side measures" was credited with initially creating as many as 410,000 jobs, delaying the now notorious unemployment problem that has plagued post-crash Spain (p. 183). This Keynesian approach was enabled by influential Keynesian economists in the government's Economic Bureau and in the Socialist Party's think tank, Fundacion Ideas. The Spanish government even benefited from the advice of global anti-austerity, Keynesian economists Joseph Stiglitz and Paul 
Krugman (p. 190). By 2009, however, the Bank of Spain was enforcing deficit control measures and the path to austerity was set (p. 192). Increasingly, since, in Ban's view the "very core of neoliberal theory" was challenged by Keynesian measures, Spain's "domestic translators" soon found hard external constraints imposed, especially from the European Union and the European Central Bank, ensuring a return to the neoliberal path, whatever the human cost (p. 194). So while embedded neoliberalism initially proved "remarkably resilient" in the face of the crash (p. 208), by 2010 "EU-level coercive mechanisms" were threatening an increasingly disembedded model (p. 209). Ban's bleak conclusion on Spain is that while domestic translations of neoliberalism matter, they will face powerful threats if they threaten the view that the country is open for business to investors and that it will prioritise the claims of investors over the social claims of citizens.

The more radical, disembedded neoliberalism in Romania led to a drastically different post-crash response. As Ban puts it, in reference to comments made by Romanian government economic advisers, "It is not every day that one hears the managing director of the IMF charged with being an ideologue of the left" (p. 210). The more radically neoliberal tendencies in Romanian economic policymaking were opposed to the IMF's suggestion that the country should "spread the costs of austerity more equitably" (ibid.), instead favouring sharp, "regressive" spending cuts. So international coercion does not explain Romania's drastic approach to austerity cuts and privatisations in the post-crash era. The 'troika' of the EU Commission, European Central Bank and IMF in fact tried, unsuccessfully "to curb the radicalism of local neoliberalism" in Romania (p. 212). This radical post-crash neoliberalism in Romania did not go unchallenged. As Ban argues throughout the book, "the untidy mechanisms of neoliberalism's ascendance entail temporary accommodations with countervailing ideas" (p. 236). In Romania, he notes, a crisis of disembedded neoliberalism took hold in the winter of 2011-2012 following the attempted privatisation of various health services, which triggered enormous anti-austerity protests, ultimately bringing down the government. From 2012 a Social Democratic Party-led government did not institute the progressive taxation system it mooted, since it was checked by the neoliberal leanings of its Liberal Party coalition partners (p. 239). And so when, by mid-2015, Romania could claim the second highest economic growth rate in the EU:

Radical neoliberals attributed this robust recovery to the deepening of disembedded neoliberalism during the early phases of the crisis, via the confidence effects and increasing competitiveness of the economy (p. 241).

Ban's argument that neoliberalism is no "steely behemoth" (p. 3) is certainly supported by his detailed analysis of the political back-and-forth, economic policy processes and exogenous pressure faced by Spanish and Romanian variants of pre- and post-crash neoliberalism. Even in 'disembedded' and 'resilient' Romanian post-crash neoliberalism, we don't find any finality - these ideas are still living, changing, and still contested. It is the singular achievement of Ban's book that is shows how 'global' neoliberalism - even narrowly defined as a macroeconomic policy orientation - plays out in different local contexts. 
In Risk and Hyperconnectivity, Hoskins and Tulloch begin their analysis of post-crash neoliberalism with a search for "alternatives to the hegemonic economic and political consensus" in the British media in 2007 and 2008 (p. 52). They note that in the wake of the crash, the Guardian was alone among broadsheet newspapers in using the term "neoliberal economics" to refer to the trends that had brought on the financial crisis ( $p$. 130). Through interviews with key journalists at the paper, including its economics editor Larry Elliott, and analysis of articles published at the time, they explore the memories at play in the post-crash debate. In particular, the authors find in the Guardian's pages at this time the invocation of "the emergence of a different political and economic future out of a collectively remembered "neoliberal" past" (p. 56). Calling for a "reinvention of Keynesian economics" (p. 60), Guardian journalists sought urgently to influence the public conversation and take it in a direction other than "business as usual'. The Times and Telegraph, unsurprisingly, Hoskins and Tulloch find, take a rather different approach, seeking to advance problem-solving in capitalist macroeconomic theory. The interest the authors take in this debate lies in its function as "a debate between journalists as public intellectuals [...] over the "goods" and "bads" of contemporary "risk society"” in the post-crash context (p. 87). It is of course vital that we understand such media debates if we are to understand the persistence and dynamics of post-crash neoliberalism, and in this sense Risk and Hyperconnectivity makes an important contribution.

The remainder of the book explores media representations and debates around the G20 demonstrations in 2009 (the first major post-crash social movement in the UK directed at the politics and economics that induced the crisis), the differing ways in which tabloid and broadsheet media have (re)produced narratives of the financial crisis, the extent to which "emergent" media such as social media enable a wider range of voices and alternatives to be heard, and, in 'Part II' of the book (which amounts to less than a third of the total text) analysis of some short "case studies". The authors question here, for example, whether new social movements associated with emergent media, such as the 'Hacked Off' campaign, "actually slows of stalls what Stuart Hall calls "the long march of the Neoliberal Revolution"'” (p. 282). In the final chapter of Risk and Hyperconnectivity (the book does not have a 'conclusion', per se), the authors argue that "the protests and risk events explored here constitute a complex battle-space of neoliberalism, risk, memory and closure and openness of the future to change" (p. 297).

While Hoskins and Tulloch's account of actually existing neoliberalism includes some fascinating research and analysis in terms of case studies, it does lack coherence as an overall text. The disjunctures in the book are perhaps explained by its production process, for example, one chapter concludes thus: "this chapter is based on a detailed narrative and discourse analysis [...] conducted by John Tulloch [...] during 2012 and 2013" (p. 87). This stitching together of what do at times feel like rather disparate analyses and themes is not helped by somewhat impenetrable and over-long sentences used to describe the authors' methodology, which are spread through the text. The claim, almost a third of the way into the book, that it "incorporates a dialogical and interdisciplinary engagement in place of the monological inner extension of a particular analytical paradigm", which is not clearly elaborated on, provides a case in point (p. 88). 
Equally, the drastically differing lengths of chapters and sections makes for a rather uneven read, contributing further to the feeling that several interesting pieces of work have been stitched together here. Sections discussing neoliberalism are often devoid of discussion of hyperconnectivity and risk, and vice versa. Such are the risks of serious attempts at co-authored interdisciplinary social science.

What the three books discussed here share is the provision of an interpretive framework or, to borrow the late John Berger's (1972) term, a 'way of seeing', postcrash neoliberalism as it plays out in practice. In particular, this helps readers to appreciate the degree to which neoliberalism is in fact contested, adapted and translated in its path to globalisation. But they also its remarkable persistence and resilience.

As Colin Crouch (2011) has argued, rather than collapsing altogether, neoliberalism experienced a "strange non-death" after the crash. Philip Mirowski's insightful analysis in Never Let a Serious Crisis Go to Waste (2013) further suggests that what he calls the "Neoliberal Thought Collective" - escaped the crisis "unscathed" because "contrary to every expectation, nothing much has been changed by the crisis" (p. 8). Mirowski is right to suggest that neoliberal economic ideas somehow survived, or were even strengthened by, the crash. But the notion that "nothing much" was changed by the crash and that "the sense of crisis passed" by 2011 (p. 1) is problematic. At the policymaking level, Mirowski is likely right, but in the UK, 2011 was just the beginning of the Conservative-Liberal Democrat coalition government's programme of deep public spending cuts. Today, the sense of crisis is doubtless more acute among those directly affected by cuts to welfare - including Council Tax benefit, disability allowances and working tax credits - and cuts to local authority budgets and local public services. This programme of austerity, like its counterparts in other crisis-hit countries, mainly targets people already in positions of relative disadvantage and vulnerability (those reliant upon welfare and local public services). The books under review here do offer specific insights into the uneven effects of post-crash neoliberalism, and it is to this question we now turn.

\section{Race, nation, and the future of post-crash neoliberalism}

Guardian journalist Gary Younge, Hoskins and Tulloch note, was, in the immediate aftermath of the crash "acutely aware of the linkages between neoliberal economic and foreign policy, migration, and issues of security and terror" (p. 131). Yet in all the arguing over fiscal stimuli and bail-outs, cuts to public services and other economic issues - and perhaps especially because Tony Blair and George W. Bush were leaving office, while Barack Obama had signalled (ultimately false or unfulfilled) intentions to dismantle the 'War on Terror' - the intersection of these issues was widely ignored. It is only now, a decade into the crisis, that we can see with clarity the degree of blurring of issues of recession, race and migration that has taken place.

The explanatory narratives that predominated in the media in the wake of the crisis for the left wing press the crisis resulted from neoliberalism or at least 'free market' economics, for the right wing press it resulted from a combination of a few bad apples or "Gordon Gekko types" and the actions of governments (Hoskins and Tulloch, p. 80) - 
have seemingly given way to racialised 'other'-blaming for the effects of the crisis. In the UK immigrants are suspected by many of causing the crisis of public services that is in fact clearly and indisputably a result of budget cuts flowing from the 2007 crash and designed by the 2010-2015 Conservative-Liberal Democrat coalition government. Thus an Ipsos MORI poll of 1,257 British adults carried out the week before the EU membership referendum in June 2016 found that "immigration has now surpassed the economy becoming the most important issue for voters", with 33 per cent of respondents mentioning it as a key issue for the referendum (Ipsos MORI, 2016). A post-referendum poll by Lord Ashcroft found an identical proportion (33 per cent) of 'leave' voting respondents said that the main reason for their vote was that leaving "offered the best chance for the UK to regain control over immigration and its own borders" (Lord Ashcroft Polls, 2016).

Apart from the view that 'immigrants' are somehow to blame for the ill effects of the financial crisis on Western societies, a specific racialised discourse has intersected with this narrative. A sense that Muslims (of whatever national heritage) are in some sense a particularly 'bad' kind of immigrant - that they don't share 'our values' or 'British values' (conveniently ignoring the fact that millions of Muslims have been born and raised in the UK and are thus a part of 'us') - has been established through panics about the threat from 'Islamist terrorism' and its alleged overlaps with the refugee crisis of 2014-present. This blurring together of post-9/11 Islamophobic sentiment with postcrash anxieties about the effects of recession and austerity is perhaps even more acute in the US, where Donald Trump came to power not only on promises to curb immigration generally, but the promise (now realised by Executive Order) to racially discriminate against Muslims at US borders, preventing people from majority Muslim countries from travelling to the US altogether.

Several passages in The Neoliberal Crisis will be especially, startlingly prescient to readers after the events of 2016 and 2017. In three contributions originally published 2010 and 2011, years before Brexit and Trump had appeared on our political horizon, Hall, Rustin and Clarke each offer valuable insights into how neoliberalism and the crash could lead to the predicament we find ourselves in today.

Hall argues that from its first entrance into the British political mainstream - initially through the waging of the Falklands War - neoliberalism was carefully blended with nationalist discourse: "Even today the market / free enterprise / private property discourse persists cheek by jowl with older conservative attachments to nation, racial homogeneity, Empire, tradition" (p. 22). Rustin, meanwhile, reminds us that the Thatcherite 'New Right' that brought neoliberalism into government in the last great 'conjuncture' (the crisis of the late 1970s) relied upon "the mobilisation of white anxieties about race" (p. 35).

Most prescient of all, however, is this warning from Rustin, originally penned in 2010:

Although the recent electoral victory of Obama and the Democrats represents a source of hope, the continuing intransigence of the Republican opposition, and the possibility that a failure of the Democrats in government might bring to office a president with a political outlook like that of Sarah Palin, is a cause for concern. 
A cause for concern indeed. Donald Trump has already far exceeded many of what were considered Palin's most worrying traits, further demonising Muslims (and immigrants in general) and targeting them with a travel ban and deliberate harassment ("extreme vetting"). This president, endorsed by the Ku Klux Klan and American Nazi Party, a billionaire enriched by the era of neoliberal globalisation, and empowered by Obama's many failures in office, appears to fit Rustin's bill rather comfortably.

John Clarke, also originally writing in 2010, emphasises that it is an error to perceive the conjuncture beginning with the financial implosion as a simply 'economic' crisis. In contrast to commonplace financial or economic reductionism in framings of the crisis, Clarke notes that one of its dimensions is a "return of the national as a political-cultural" and that in the context of the crisis:

[T] he revitalisation of nationalism [...] is a distinctive political-cultural phenomenon in which postcolonial legacies meet a variety of other elements - anti-Muslim orientalism, anti-migrant localism, and the reinvention of nationality as a claims making identity (p. 53).

But it is not just the special, and little-explored synergy between nationalism, racism and neoliberalism that is at stake in Brexit and Trump. Clarke also describes the depoliticisation that neoliberalism has encouraged, the increasing scepticism and cynicism about politics among ordinary people. He laments the "characteristically populist juxtaposition of the people against the political class" (p. 57) and issues this dire warning in conclusion:

This mixture of popular desires and doubts is a profoundly unstable one, and at present appears vulnerable to being captured by varieties of nationalist and racialised imaginaries of exclusion - excluding others or excluding ourselves from the larger world (p. 58).

In the book's concluding chapter, Doreen Massey notes that while "we face a continuing economic crisis in the UK [...] there is no real crisis in the ideological formation" of neoliberalism outlined by Stuart Hall in the book's first chapter (p. 102). On the book's publication in 2015, such an argument could hold. In 2017, we must re-assess; are we now living through precisely the ideological crisis Massey refers to? It should, therefore, be recognised that one of the key achievements of The Neoliberal Crisis in pulling together several years' worth of the Soundings editors' analyses is to highlight that, had more attention been paid to such analysis, neither Brexit nor Trump should have come as a surprise. By implication, we can also suggest that neither was inevitable. Had the central call of both The Kilburn Manifesto and The Neoliberal Crisis - a call to avoid a return to 'business as usual' in the face of the economic crisis - been heeded, we might not find ourselves in a world where the UK is leaving the EU and a quasi-fascist billionaire television presenter is President of the United States.

\section{Conclusion}

The three texts explored here make important contributions to our understanding of neoliberalism in at least three ways, each of which has been addressed in this article. First, they offer theories or definitions of neoliberalism, each with a specific intellectual heritage, and often overlapping but, as this article has shown, sometimes standing in 
opposition to one another. Second, the three books offer analyses of how and why neoliberalism works in practice in the post-crash era. And finally, the books - in particular The Neoliberal Crisis - offer some explanation for the emerging political crisis of 2016-17, its inter-relation with the financial crash and crisis of 2007-present and with neoliberalism in general.

These contributions are important not only because they further our understanding of the drastic social and political changes initiated by the crash from 2007 onward, but also because they might offer a key to understanding more recent changes and the present trajectory of Western political-economic and social trends. These books were all published shortly before two ostensibly sea-change events - the UK's referendum vote to leave the European Union and Donald Trump's election as President of the United States. As this article has made plain, and in common with the vast majority of literature on the topic of neoliberalism, all three books adopt a 'critical' stance toward their subject matter. Critical economic scholarship, from Ann Pettifor to Joseph Stiglitz, had warned us that the financial crash was coming, but was not taken seriously by political-economic decision-makers. After the crash, as this article has shown, critical scholarship also warned us in advance of the slide into white nationalism and far right 'populism' that mainstream Western politicians of more or less all stripes lament today. Again, those in power ignored these critical voices and strived for 'business as usual'. Politicians and economists would do well to begin paying urgent attention to books like these, if they truly hope to find any way past the present crisis of the Western political mainstream.

\section{References}

Amable, B. (2011) 'Morals and politics of neoliberal ideology', Socio-Economic Review, Vol. 9, pp. 3-30.

Barnett, C. (2005), 'The consolations of 'neoliberalism”, Geoforum, Vol. 36, No. 1, pp. 712.

Berger, J. (1972), Ways of Seeing, London: Penguin/BBC.

Boas, T.C. and Gans-Morse, J. (2009) 'Neoliberalism: From New Liberal Philosophy to Anti-Liberal Slogan', Studies in Comparative International Development, Vol. 44 No. 2, pp.137-161

Brenner, N. and Theodore, N. (2002) 'Cities and Geographies of "Actually Existing Neoliberalism”', Antipode, Vol. 34, No. 3, pp. 349-379.

Chandler, D. (2014) 'Beyond Neoliberalism: resilience, the new art of governing complexity', Resilience, Vol. 2, No. 1, pp. 47-63.

Crouch, C. (2011), The Strange Non-Death of Neoliberalism, Cambridge: Polity.

Friedman, M. (2002) Capitalism and Freedom, Chicago: Chicago University Press.

Hall, S. Massey, D. and Rustin, M. (2015) 'Framing Statement - After Neoliberalism: Analysing the Present' in Hall, S. Massey, D. and Rustin, M. (eds.) After Neoliberalism? The Kilburn Manifesto, London: Lawrence and Wishart Ltd. 
Hayek, F.A. (1944), The Road to Serfdom, London: George Routledge \& Sons.

Ipsos MORI, 'Immigration is now the top issue for voters in the EU referendum', https://www.ipsos-

mori.com/researchpublications/researcharchive/3746/Immigration-is-now-thetop-issue-for-voters-in-the-EU-referendum.aspx [accessed 5th March 2017, 14:00].

Lord Ashcroft Polls, 'How the United Kingdom voted on Thursday... and why', http://lordashcroftpolls.com/2016/06/how-the-united-kingdom-voted-andwhy/ [accessed 2nd March 2017, 15:00].

Mirowski, P. (2013), Never Let a Serious Crisis go to Waste: How Neoliberalism Survived the Financial Meltdown, London: Verso.

Nove, A. (2013), Marxism and "Really Existing Socialism", Abingdon: Routledge.

Schwarzmantel, J. (2008), Ideology and Politics, London: Sage.

Steger, M.B. (2005), Globalism: Market Ideology Meets Terrorism, Lanham: Rowman and Littlefield Publishers.

Steger, M.B. and Roy, R.K. (2010), Neoliberalism: A Very Short Introduction, New York: OUP.

Wikipedia (2017), 'Neoliberalism', https://en.wikipedia.org/wiki/Neoliberalism [accessed 5th March 2017, 13:00]. 